\title{
On the Otherness of Shylock in The Merchant of Venice
}

\author{
HUANG Li-hua \\ Guangdong Peizheng College; Guangdong University of Foreign Studies, Guangzhou, China

\begin{abstract}
Compared with the other characters in The Merchant of Venice, Shylock seems to be totally an outsider and alien of Venice which is because he is considered to be the "Other" in the eyes of the other Venetians as a result of his identity a Jew as well as his occupation as a usurer, both of which are despised and degraded at the Elizabethan
\end{abstract} \\ times.
}

Keywords: otherness, Shylock, The Merchant of Venice, Jew, usurer

\section{Introduction}

Shylock is the antagonist of the play The Merchant of Venice, who is often considered to be a villainous comic character. He is a Jew as well as a usurer because of which he is often scorned and abused by one of the protagonists Antonio and his friends. Nevertheless, one day Antonio has to turn to Shylock for help as he needs 3,000 ducats to assure his dearest friend Bassanio's courtship for a richly left lady Portia, while all his money has been invested in the merchant vessels at sea. Shylock agrees to lend him money on the provision that if the money is not repaid within three months, he will claim one pound of Antonio's flesh as his forfeit. Before long, his daughter elopes with Lorenzo, another friend of Antonio with a lot of his property and converts to Christianity. Just as he is caught in deep distress and wild rage, news comes that all of Antonio's ships may have lost at sea. Shylock then decides to claim his forfeit and avenge all the grief and misfortune as well as the insult and mistreatment he has suffered because of Antonio. He turns down not only the request for mercy from the Duke and the lawyer but also the offer of double or even 10 times the principal from Bassanio and insists on the justice of law for the legal claim of one pound of Antonio's flesh. However, just as he is about to cut the flesh, he is trapped by the lawyer disguised by Portia by one of the flaw in his bond as well as by one almost forgotten item of the Venetian law holding on him due to which his estate runs the risk of being confiscated and his life is in great danger. In the end he has to accept Antonio's terms, that is, besides giving half of his possession to Antonio, he has to convert to Christianity and make a will to leave all his possessions to his daughter and his son-in-law Lorenzo after his death. Totally defeated the Jew leaves the stage miserably and desperately. Compared with the other characters in The Merchant of Venice, Shylock seems to be totally an outsider and alien of Venice because he is considered to be the "Other" in the eyes of the other Venetians as a result of his identity a Jew as well as his occupation as a usurer, both of which are despised and degraded at the Elizabethan times.

HUANG Li-hua, M.A., Lecturer, School of Foreign Languages, Guangdong Peizheng College; Guangdong University of Foreign Studies, Guangzhou, China. 


\section{The Otherness of Shylock}

The term "Other" together with its other variations such as its noun form "otherness" and verb form othering is often used in psychoanalysis, post-colonialism, and cultural studies. There are also various definitions available for the word and its variations. Longman Dictionary of Contemporary English defines otherness as "the quality of being strange or different” (2004, p. 1385). Cambridge International Dictionary of English provides a more detailed definition: "Otherness is the quality of being different in appearance or character from what is familiar, expected or generally accepted” (2001, p. 1767). Jeremy Hawthorn puts otherness like this:

To characterize a person, group, or institution as "other" is to place them outside the system of normality or Convention to which one belongs oneself. Such an activity is referred to by some theorists by means of a verb form: othering. Processes of exclusion by categorization are central to certain Ideological mechanisms. (2000, p. 249)

In addition to this definition, he also mentions the word otherness in terms of Jacques Lacan's psychoanalytical theory and Lynne Pearce's definition of her term textual other. The otherness discussed here is mainly in the sense of culture, to be exact, of ethnicity, religion, and the social identity of the individual. The otherness of Shylock is mainly concerned with his ethnic identity as a Jew and his religious belief of Judaism in the context of the Gentile society and the Christian culture as well as his occupation as a usurer in the context of the mercantile Venice.

Patrick Swinden claims that “There weren’t many Jews in Elizabethan London [...] So they could be put to work very well as strange bogeymen both in the Elizabethan and Restoration periods [...]” (1979, p. 66). Roma Gill holds that the reasons why the Jew was a figure hated and feared by the Elizabethans are not at all simple. He considers superstition to be the main reason, which arises out of medieval legends such as that of St. Hugh of Lincoln, a little boy who was said to have been crucified by Jews. He goes on to explain that "true religious hostility was rare, but religion gave the English Christians a good excuse for persecuting the foreigners who had come to live amongst them” (1997, p. xi). In contrast, one of the reasons for the Elizabethans' hatred and fear towards Jews given by Patrick Swinden sounds more acceptable; he says that during Shakespeare's composition of the play, "a Portuguese Jew, Roderigo Lopez, physician to Queen Elizabeth, was being tried and executed for plotting the murder of the Queen and the pretender to the throne of Portugal” (1979, p. 67). According to Swinden "this would presumably have affected Shakespeare's portrait of the Jew" as "there is a passage in Act 4, Scene 1, in which Shylock is compared with a wolf (lupus)" which has once been used to refer to the Portuguese physician (1979, p. 67).

The Elizabethans also hated the traditional Jewish profession of usury - the lending of money for profit. Jews were often forbidden to own land or to engage in trade in England; consequently the only lucrative profession open to them was money-lending. (Gill, 1997, p. xxix)

Since as Stephen Orgel says "There are Christian moneylenders who charge no interest" (2003, p. 153), Shylock's occupation as a usurer, a money-lender who does charge interest, also makes him the object of being despised and disliked. All in all, "Shylock starts from a double disadvantage, as far as an Elizabethan audience was concerned. He is a Jew, and he is a moneylender" (Gill, 1997, p. xxix). Conspicuously, the situation of Shylock quite satisfies the definition of the "Other" cited above: He is a stranger and a foreigner as well as an outsider and an alien "marginalized and firmly placed on the fringe of society"; he does not "fit the norm” which 
has been largely determined by the Christian Venetian society. Therefore, it is absolutely safe for us to define Shylock as an "Other" in the play.

Besides his disadvantageous double identity, his otherness is also represented by other people's attitudes towards him. Antonio often scolds him in the Rialto about his money and his financial deals and calls him "misbeliever, cut-throat dog", and spit on him (1.3.102-8). He compares Shylock to the devil with evil soul, "a villain with a smiling cheek" and "a goodly apple rotten at the heart" (1.3.94-8) and also to "a wolf" (4.1.73) at other times. Bassanio addresses Shylock as "a villain” (1.3.175), "unfeeling man” (4.1.63), "the cruel devil” (4.1.215) and "this devil” (4.1.288) as well. Their friend Solanio calls Shylock "the villain Jew" (2.8.4), "the dog Jew” (2.8.14), “old carrion” (3.1.33), "the devil” (3.1.19/3.1.74), as well as "the most impenetrable cur that ever kept with men” (3.3.18-9). Another friend Salerio also refers to Shylock as "the devil” (3.1.31) and "a creature” he has never known "that did bear the shape of man,/So keen and greedy to confound a man" (3.2.273-5). Gratiano calls Shylock: "this currish Jew” (4.1.290), and "damn'd, inexorable dog” and as his desires are "wolvish, bloody, starv'd, and ravenous"; he is just like "the currish spirit govern'd a wolf, who, hang'd for human slaughter" (4.1.128-38). The duke looks on Shylock as "a stony adversary" of Antonio and "an inhuman wretch uncapable of pity, void and empty from any dram of mercy” (4.1.3-6). His son-in-law Lorenzo considers him to be a man who has "no music in himself" and cannot be moved "with concord of sweet sounds", and an untrustworthy man who is "fit for treasons, stratagems, and spoils" and who has dull motions of spirit and dark affections (5.1.83-4). Launcelot Gobbo, Shylock's servant, runs away from him as he thinks of Shylock, his master as "a kind of devil” (2.2.23) and actually "the very devil incarnation” (2.2.26-7). He says that Shylock has starved him to skin and bone (2.2.102-3). He tells Bassanio that the Jew has done him wrong (2.2.126-7). He runs away for fear that: "For I am a Jew, if I serve the Jew any longer" (2.2.108-9).

Even his daughter Jessica, although she herself is an "other" in the Venice, dislikes him and leaves him. Jessica says "the house is hell" and very tedious (2.3.2-3). She regards it "heinous $\sin [\ldots]$ to be asham'd to be my father's child!” However, she thinks “though I am a daughter to his blood, I am not to his manners” (2.3.18-9). His manners here refer to his behavior, which Marilyn French describes as puritanical which is quite different or even totally against the grain of the merry-making one of the other Venetians. He says that "Shylock's house, according to both Launcelot Gobbo and Jessica, is joyless and sparse; sensuous pleasure is forbidden, whether it be food or drink, music or dancing, or even watching others at pleasure” (French, 1982, p. 102); when he learns that there will be masques, he warns Jessica to:

\footnotetext{
Lock up my doors, and when you hear the drum And the vile squealing of the wry-neck'd fife, Clamber not you up to the casements then, Not thrust your head into the public street To gaze on Christian fools with vanish'd faces, But stop my house's ears - I mean my casementsLet not the sound of shallow foppery enter My sober house [...] (2.5.28-36)
}

However, Jessica chooses to end all this conflict by converting to Christianity and becoming a Christian's loving wife (2.3.16-21). In doing so, not only does she change her status as an "other", she also strengthens her father's status as an "other". The Venetians seem to be rather tolerant and generous towards a converted Jewish 
girl, as Gratiano says to his friends about Jessica: “Now, by my hood, a gentle, and no Jew” (2.6.51). When Shylock puts Jessica's elopement with Lorenzo, theft of the money and betrayal of their faith as a curse upon their nation (3.1.80-2) and curses "She is damned for it" (3.1.30), Solerio defends that "That's certain, if the devil may be her judge" (3.1.31). When he says that his daughter is his flesh and his blood" (3.1.34), Salerio points out that "There is more difference between thy flesh and hers than between jet and ivory; more between your bloods than there is between red wine and Rhenis" (3.1.35-7). The only one who seems to still put her at her status of the "other" is Launcelot Gobbo, who holds that there is no place for Jessica in heaven, because she is the daughter of a Jew and the sins of both her father and mother are to be laid on her (3.5.1-11). When Jessica insists that she can be saved by her husband who has made her a Christian (3.5.18-9), Launcelot, however, condemns Lorenzo for the possibility of raising the price of pork in converting Jews to Christians (3.5.20-5). Nevertheless, being a comic clown in the play, Launcelot, together with his opinion, will neither influence the others' opinions, nor make any difference to the present status and the future fate of Jessica. On the whole, it is like what Warren D. Smith has said: "The Christians in Venice treat Jessica as an equal, and Portia and Nerissa in Belmont welcome her as a sister” (1992, p. 346).

Shylock is conscious of his status as the "Other" from the very beginning, but he denies it and tries to defend and justify his identity as a Jew, and his occupation as a usurer. He holds tightly his ethnical pride, and protests strongly against Christianity and hates the Christians deeply. As D. J. Palmer observes when contenting with Antonio about the rights and wrongs of usury in Act 1 Scene 3, "Shylock grounds his justification for usury on Scriptural authority, citing as precedent the account in Genesis 30 of how Jacob earned his hire as shepherd to his uncle Laban” (1972, p. 98). While Shylock is in praise of Jacob's cunningness and craftiness, by saying "This was way to thrive, and he was blest:/And thrift is blessing, if men steal it not" (1.3.85-6), Antonio ascribes Jacob's success to the hand of God and mocks him that his gold and silver cannot be ewes and rams (3.1.87-91). But Shylock insists that his gold does breed only not so fast (3.1.92). In order to remove Antonio's prejudice and discrimination for him, Shylock decides to lend him money. Knowing that he never lends or borrows money upon advantage, Shylock suggests a "merry sport”, or a “merry bond” with one pound of Antonio's flesh for forfeit if the money cannot be repaid before the due time (1.3.65ff). However, Antonio does not seem to be grateful. He would rather that Shylock lends the money to him as an enemy than a friend, and claims that he will go on abusing him, spiting on him, and spurning him (1.3.126-33). Shylock pleads them not to wrong him for his love and his kind offer. He expresses that it he would like to be friends with him and have his love and that he would forget all the shames Antonio has stained him with (1.3.134-8). He also assures Antonio that the bond is completely a joke, as a pound of man's flesh is not even as valuable and profitable as flesh of some of the animals, and he emphasizes again the purpose of the bond, that is, "To buy his favor, I extend this friendship" (1.3.156-66). In doing and saying so, Shylock makes an attempt to reduce or erase his inferior status as an "other", and to become at least equal as friends or even superior as a creditor to the debtor. So after signing the contract, although he knows that Bassanio does not invite him to the banquet for love, despite his bad dream about his money-bags (2.5.14-8) and his assertion that "I will buy with you, sell with you, talk with you,/Walk with you, and so following; but I will not eat/With you, drink with you, nor pray with you [...]" (1.3.32-4), he will "go in hate, to feed upon the prodigal Christian” (2.5.14-5). 
At the same time his hatred for the Christians especially for Antonio is as much as or even more than that of theirs for him. To some extent, Shylock also has the intention to other the Christians. He thinks all the Christians especially Bassanio and Antonio as prodigal (2.5.15/3.1.41); he also despises these prodigal and unfaithful husbands who would sacrifice the lives of their wives to save their friend (4.1.188-90/4.1.282-8) and who easily give away the wedding rings they have sworn they will never part to strangers, while he himself acts as a faithful one by keeping his wife's token of love in his bachelorhood life long and "would not have given it for a wilderness of monkeys" (3.1.116-7), so he would marry his daughter to "any of the stock of Barabas [...] rather a Christian!” (4.1.293-5); he calls Launcelot "the fool of Hagar's offspring” (2.5.44) and considers his change of employment to Bassanio one way to "help to waste his borrow'd purse" (2.5.50-1); more often than not, he talks about the reason for his hatred of Antonio and demands revenge:

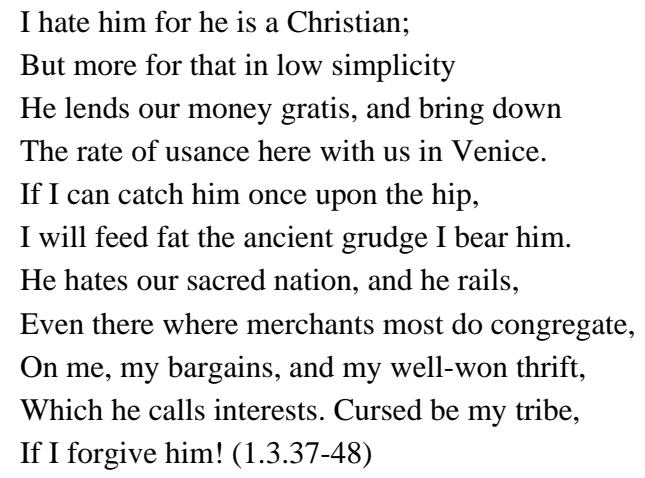

Obviously, Shylock hates him for Antonio is the quite opposite to him, an "other" in his eyes, who is a gentile and a money-lender who lends money free of interest, and who disdains and abuses his sacred nation and his ethnic pride and dignity. But he has "borne it with a patient shrug,/For sufferance is the badge of all our tribe (1.3.102-25). Graham Midgley considers Jessica’s elopement to be the crucial point in Shylock’s development,

In this deed a blow is struck at all that Shylock holds dear, his pride of race, the sober decency of his household life and the dear sanctity of the family and family bonds. The mixing of ducats with his daughter in his cries of despair is because his ducats, as his daughter, are part of his family pride, the only bulwarks against the general scorn of the society he lives in [...] (1969, p. 198)

And by marrying a prodigal Christian and converting to Christianity, his daughter betrays their race and religion, which is a great disgrace and shame for him; while her theft of his money adds to his rage and anguish, with this kind of confused emotion, he claims that: "I would my daughter were dead at my foot, and the jewels in her ear! Would she were hearsed at my foot, and the ducats in her coffin!” (3.1.84-6). It is his daughter's runaway that has brought all this accumulated rancor into eruption and the long repressed and hidden emotions overt which burst out in his powerful speech in which he insists that Antonio's flesh will feed his revenge, because "He hath disgraced me, and hindered me half a million, laughed at my losses, mocked at my gains, scorned my nation, thwarted my bargains, cooled my friends, heated mine enemies [...]" (3.1.49-54). All at last he is determined to avenge all his loss and pain on Antonio with the hope that "were he out of Venice, I can make what merchandise I will” (3.1.120-2) at least as a way to retrieve the ducats he has lost. His speech continues like this: 
And what is his reason? I am a Jew. Hath not a Jew eyes? Hath not a Jew hands, organs, dimensions, senses, affections, passions? Fed with the same food, hurt with the same weapons, subject to the same diseases, healed by the same means, warmed and cooled by the same winter and summer, as a Christian is? If you prick us, do we not bleed? If you tickle us, do we not laugh? If you poison us, do we not die? (3.1.54-62)

His speech, according to Roma Gill, apparently "appeals to our common humanity. To give a negative answer to his questions would deny not his humanity, but our own” (1997, p. xxxi). As Hawthorn says, "If members of a given racial group are collectively seen as other, then how they are treated is irrelevant to what humanity demands-because they are other and not human" (2000, p. 249). Georges Devereux claims that "(Ethnic identity) is logically and historically the product of the assertion that ' $\mathrm{A}$ is an $\mathrm{X}$ because he is not a $\mathrm{Y}$ '” (Sollors, 1990, p. 288), which is according to Sollors "a proposition which makes it remarkably easy to identify Xness". However, "the definition of Xs as non-Ys threatens to exaggerate their differences in such a way that if the Xs think of themselves as human, they may therefore consider the Ys as somehow nonhuman” (Sollors, 1990, p. 288). Here, in the first part of his speech, "Shylock expresses the view that though a Jew, he is as much a man as any of the worldly Venetians who taunt and despise him” (Swinden, 1979, p. 2), or as E. F. C. Ludowyk says "a Jew, because he is as much a human being as any Christian, should therefore be treated accordingly" (Scott, 1992, p. 303), which implies that "Common humanity ignores all limitations of color, race, or creed” (Gill, 1997, p. xxxi). Here come the last lines of his speech:

And if you wrong us, shall we not revenge? If we are like you in the rest, we will resemble you in that. If a Jew wrong a Christian, what is his humanity? Revenge! If a Christian wrong a Jew, what should his sufferance be by Christian example? Why, revenge! The Villainy you teach me I will execute, and it shall go hard but I will better the instruction. (3.1.62-9)

For Ludowyk,

Their intention is to prove that as Jews and Christians are both human beings, it is natural for them both to revenge wrongs done them - a point of view which would seem damnable both to orthodox Christian opinion and Jewish. (Scott, 1992, p. 303)

Bradshaw thinks of it as “attempts to justify an appalling act of inhuman vengefulness” (1987, pp. 24-25) and cruelty. Roma Gill claims that "the assertion of these last lines show that the individual—Shylock—is determined to ignore the limits of humanity. He will "better the instruction”, and prove himself to be not the equal of the Christians in inflicting suffering on others, but their superior” (1997, p. xxxi).

Hence, when asked to show his mercy, he obstinately sticks to his bond and his initial intention saying "I crave the law" (4.1.204-5), "There is no power in the tongue of man to alter me. I stay hereon my bond" (4.1.238-40), although he himself knows clearly that the reason why he prefers Antonio's flesh to multipled ducats is according to Gill rather irrational and emotional just as some people hate a gaping pig, are mad at the sight of a cat or cannot contain their urine at the sound of the bagpipe (1997, p. xxv). Nonetheless, he says it is his humor just as he is pleased to get a troubled rat out of his house at the cost of 10,000 ducats. He considers prejudice to be the reason why he carries on this losing suit against Antonio (4.1.38-62) and points out how it works: “[...] affection,/Master of passion, sways it to the mood/Of what it likes and loathes” (4.1.50-2).

He calls it "affection”, and shows the relationship between prejudice and the emotions [...] If we are prejudiced, we may dislike someone for no other reason than that he is different from us in nationality, religion, color, or social class. (Gill, 1997, p. ix) 
He also adds that the justice of his claim of Antonio's flesh is as that of the Christians' claim of the purchased slaves that they treat as asses, dogs, and mules (4.1.90-100), which according to W. H. Auden, "points out that those who preach mercy and brotherhood as universal obligations limit them in practice and are prepared to treat certain classes of human beings as things” (1967, p. 146). Shylock is quite confident that the duke will grant him justice; if not, "There is no force in the decrees of Venice" (4.1.102), and "Venice will suffer in its reputation as the centre of international trade” (Gill, 1997, p. xxv) as Antonio has mentioned earlier (3.3.26-31). In contrast to his previous status as an "other", who "has been ridiculed and humiliated and treated more badly than a dog" (Kofman, 1990, p. 160), Shylock now becomes a worm that finally turns. Sarah Kofman claims that,

Shylock prefers the torture of Antonio to his money, for that is the basis of this strange and subterranean logic: watching or causing suffering brings pleasure, and this pleasure is intensified by the fact that the debtor is a master who is hierachically superior to the creditor who, through the unexpected spectacle [...] can thus, reversing the roles, assure the role of master, assume, that is, a right to cruelty, exert his power over a person reduced to powerlessness and voluptuously enjoy this dish [...] In operating this reversal of mastery, Shylock not only fully satisfies his will to power but, in showing that he prefers revenge to money, he reveals his "spirituality" to those who have denied it and, beyond established social and racial differences, proclaims the universality of instincts, notably that of cruelty [...] (1990, pp. 160-161)

Therefore, "Shylock flaunts his personal superiority and the strength of his case before the court" (Jensen, 1991, p. 37). And neither the insults and abuses from Gratiano nor the pleadings from the duke and the lawyer spoil the enjoyment of his triumph. However, there happens a dramatic turnaround during the crises. Shylock is trapped step by step into his destruction. His confident, eloquent, and powerful speeches are gradually replaced by fewer and fewer words until total silence and his humbler and humbler requests are turned down one by one and with Antonio's power restored, Shylock is finally reduced to complete powerlessness. No matter how hard he tries to defend his identity, no matter how hard he tries to take advantage of the Christians, his status still remains inferior and other. "A Jew is not regarded, even in law, as a brother" (Auden, 1967, p. 148). He is "finally overcome completely through the congregated social and legal powers of that society" stripped of half of his wealth and deprived of his faith, to say nothing of the loss of his daughter, his ducats, his ring, his occupation, and even his identity. Actually there's nothing left for him but "the badge of entrée, to become a member of society in which he has always been an outcast—he is to be made a Christian” (Midgley, 1969, pp. 204-205).

\section{Conclusion}

In conclusion,

Shylock is a Jew in a Gentile society that all he is and all he holds dear is alien to the society in which he has to live. He is an alien, an outsider, tolerated but never accepted [...] He is a stranger, proud of his race and its traditions, strict in his religion. [...] (Midgley, 1969, p. 196)

He is the "Other" in the eyes of the other Venetians, in the world of The Merchant of Venice as well as in the Elizabethan times as a result of his disadvantageous double identities as both a Jew and a usurer. "Certainly, the usurer is necessary to the world of The Merchant of Venice. Shylock's wealth is evidence of his professional success, which could only come from satisfying a social need” (Gill, 1997, p. xxix), however, as Hawthorn says "If woman is other, then that which is particular to the experience of being a woman is irrelevant to "how things are”, to the defining conventions by which one lives (2000, p. 249). It is the same with a Jew, that is, "attitudes to 
the Jew do not seem to have been based on experience of these people. Rather, it seems that the stereotypes were based on an essentially theological conception of the status of Jews as non-Christians" (Appiah, 1990, p. 278). Therefore, "Shylock is a professional usurer who, like a prostitute, has a social function but is an outcast from the community” (Auden, 1967, p. 147).

Nevertheless, Shylock denies his status as the "Other" and makes every effort to defend and justify his identity and at the same time attempts to other the Christians. "Shylock rejects the Christian community as firmly as it rejects him. Shylock and Antonio are at one in refusing to acknowledge a common brotherhood [...]" (Auden, 1967, pp. 146-147). "He outwardly opposes the whole society and outrages its pride and its code [...]" (Midgley, 1969, p. 204) and strongly appeals to justice, equality, and humanity, but "Christian and Jew mutually charging one another with an inhumanity which is common to both parties” (Palmer, 1967, p. 136). "Shylock, carrying his hatred to extremes, exposes the injustice and ferocity of the social institutions from which it springs" (Palmer, 1967, p. 135). Shylock is doomed to lose his power and his voice and all that he is as an "Other" as according to the online definition of "Otherness" and that of Jeremy Hawthorn's (2000, p. 249); the Jews do not fit the norm—a norm that has been largely determined by the predominantly Christian society, so that they are placed outside the system of normality or Convention as "other".

\section{References}

Appiah, K. A. (1990). Race. In F. Lentricchia \& T. McLaughlin (Eds.), Critical terms for literary study (pp. 274-287). Chicago and London: The University of Chicago Press.

Auden, W. H. (1967). Brothers and others. In L. Lerner (Ed.), Shakespeare's comedies: An anthology of modern criticism (pp. 23-36). London: Penguin Books.

Bradshaw, G. (1987). Shakespeare's scepticism. Sussex: The Harvest Press.

French, M. (1982). Shakespeare's division of experience. London: Jonathan Cape Ltd.

Gill, R. (Ed.). (1997). Oxford School Shakespeare: The merchant of venice. Beijing: Foreign Language Teaching and Research Press.

Hawthorn, J. (2000). A glossary of contemporary literary theory (4th ed.). London: Arnold.

Jensen, E. J. (1991). Crowning the end: The aggrandizement of closure in the reading of Shakespeare's comedies. Shakespeare and the ends of comedy. Bloomington, Indiana: Indiana University Press.

Kofman, S. (1990). Conventions: The merchant of venice under the sign of saturn. In P. Collier \& H. Geyer-Ryan (Eds.), Literary theory today (pp. 142-166). Cambridge: Polity Press.

Longman dictionary of contemporary English. (2004). Ed. Pearson Education Asia Limited. New Edition. Beijing: Foreign Language Teaching and Research Press and Longman.

Midgley, G. (1969). The merchant of venice: A reconsideration. In J. Wilders (Ed.), Shakespeare: The merchant of venice (pp. 193-207). London and Basingstoke: The Macmillan Press Ltd.

Orgel, S. (2003). Imagining Shakespeare: A history of texts and visions. New York: Palgrave Macmillan.

Palmer, D. J. (1972). The merchant of venice, or the importance of being earnest. In M. Bradbury \& D. Palmer (Eds.), Stratford-upon-Avon studies 14: Shakespearian comedy. London: Edward Arnold Ltd.

Palmer, J. (1967). Shylock. In L. Lerner (Ed.), Shakespeare's comedies: An anthology of modern criticism. London: Penguin Books.

Procter, P. (Ed.). (2001). Cambridge international dictionary of English. Shanghai: Shanghai Foreign Language Education Press. Scott, M. W. (Ed.). (1992). Shakespeare for students. Book I. Detroit: Gale Research Inc.

Smith, W. D. (1992). Shakespeare’s Shylock. In M. W. Scott (Ed.), Shakespeare for students. Book I (pp. 344-347). Detroit: Gale Research Inc.

Sollors, W. (1990). Ethnicity. In F. Lentricchia \& T. McLaughlin (Eds.), Critical terms for literary study (pp. 288-305). Chicago and London: The University of Chicago Press.

Swinden, P. (1979). An introduction to Shakespeare’s comedies. 1973. London and Basingstoke: The Macmillan Press Ltd. 